\title{
Trajectory of the Greek financial crisis
}

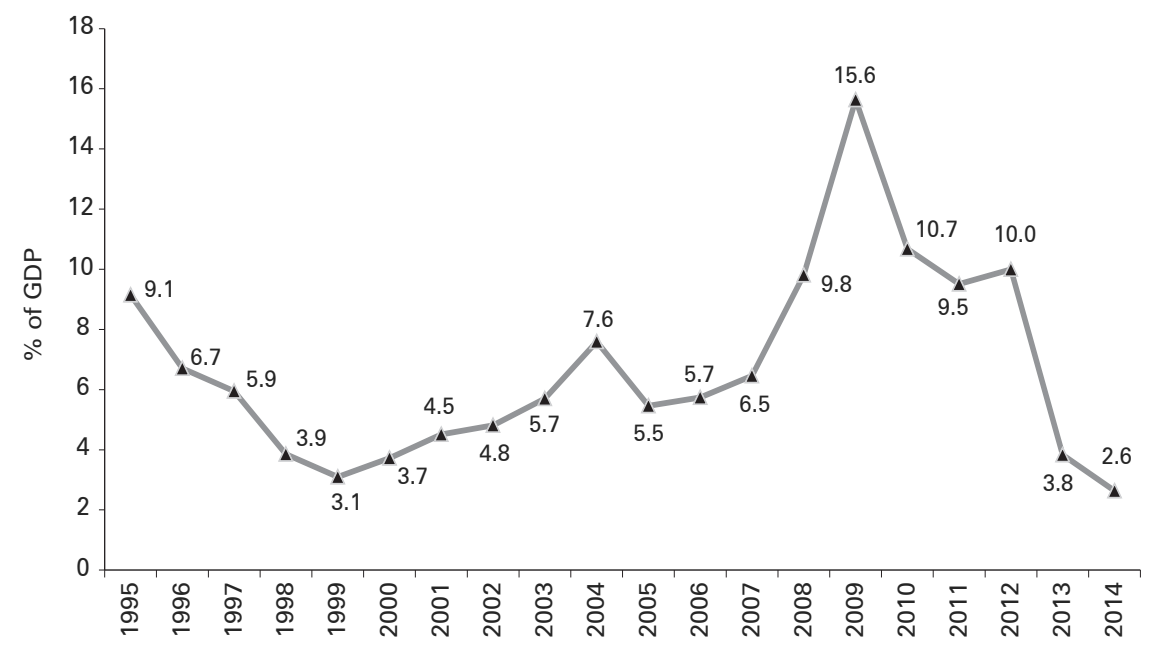

Figure 1 Greece's deficit as a percentage of gross domestic product, 1995-2014. Source: European Commission 


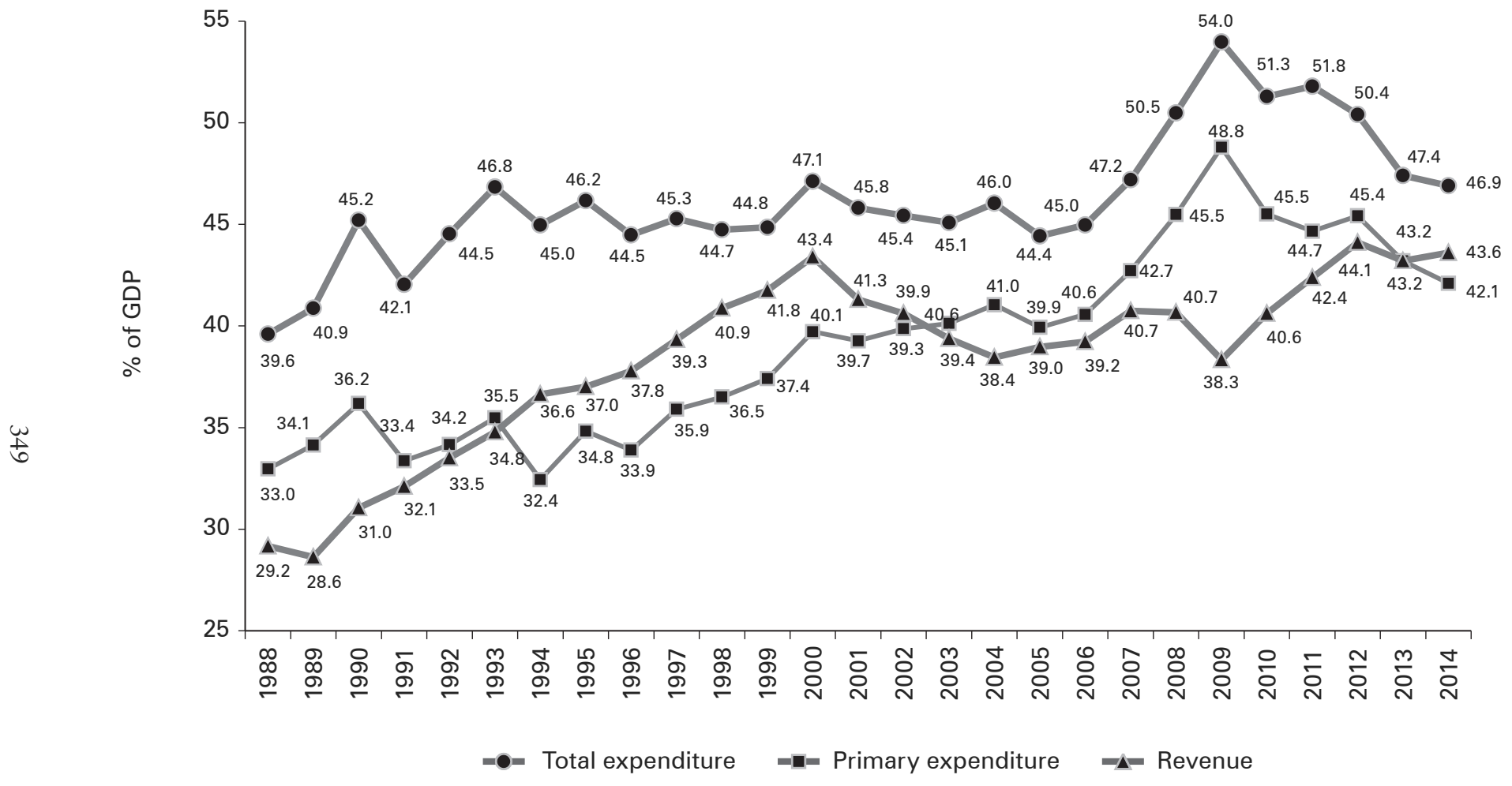

Figure 2 Greece's expenditure and revenue, as a percentage of gross domestic product, 1988-2014 (total expenditure is primary expenditure plus debt repayment). Source: European Commission 